\title{
Sistem Pembiayaan dan Skema Kelembagaan Jaminan Kesehatan Daerah Kota Yogyakarta
}

\author{
Cost System and Institution Local Health Insurance Scheme of \\ Yogyakarta City
}

\section{Sunarto}

Fakultas Kedokteran Universitas Islam Indonesia Yogyakarta

\begin{abstract}
Abstrak
Negara menyelenggarakan Sistem Jaminan Sosial Nasional sebagai sistem penyelenggara program negara dan pemerintah untuk memberikan perlindungan sosial agar setiap penduduk dapat memenuhi kebutuhan dasar hidup layak. Jaminan sosial kesehatan bertujuan memberi kepastian perlindungan kesejahteraan sosial kesehatan agar setiap penduduk dapat memenuhi kebutuhan hidupnya menuju terwujudnya kesejahteraan sosial bagi seluruh masyarakat Indonesia. Penelitian ini bertujuan untuk mengidentifikasi masalah, hambatan, dan tantangan yang berkaitan dengan sistem pembiayaan dan skema kelembagaan Jaminan Kesehatan Daerah (Jamkesda) yang sudah dikembangkan selama ini. Penelitian ini merupakan desain studi kasus menggunakan metode kualitatif dengan pendekatan analisis kebijakan retrospektif. Analisis kebijakan ini berorientasi pada aplikasi dengan melakukan identifikasi masalah dalam sistem pembiayaan dan skema kelembagaan. Hasil penelitian meliputi, pertama sistem pembiayaan yang digunakan pemerintah kota belum sepenuhnya menerapkan prospective payment system, tetapi dikombinasikan dengan sistem retrospective payment. Jamkesda Kota Yogyakarta belum sepenuhnya mengadopsi sistem Jaminan Pemeliharaan Kesehatan Masyarakat, pembiayaan sepenuhnya bersumber pada Anggaran Pengeluaran dan Belanja Daerah (APBD). Skema kelembagaan menghadapi kendala pengelolaan keuangan oleh pihak Unit Pelaksana Teknis Penyelenggara Jaminan Kesehatan Daerah (UPT PJKD). Kewenangan mengelola dana belum bersifat otonom sehingga mekanisme pencairan klaim lambat. Keterbatasan jumlah personil berimplikasi pada efektivitas lembaga melayani penerima manfaat.
\end{abstract}

Kata kunci: Jaminan kesehatan daerah, sistem pembiayaan, skema kelembagaan

\section{Abstract}

State using national health insurance system as a state system and government to give social protection so that each people can fullfil human basic needs. Health social insurance to give protect ensurement health social welfare so that each people can fullfil life need for social welfare Indonesian people. To identify the problems, obstacle, and challenge with cost system and scheme of institution Local Health Insurance which has develop to day. This research is case study using qualitative method with retrospective policy analyzed approach. This analyzed policy oriented to aplication with identify the problems in cost system and scheme of institution. Show that, first in cost system which used by local government not yet application prospective payment system fullfily but combine with retrospective payment. Local Health Insurance in Yogyakarta not yet adopt maintenance of public health insurance (JPKM) system. Cost sourcees from local revenue and expenditure budget (APBD). Second, scheme of institution still have problems to control money by technical implementation unit of local health insurance providers (UPT PJKD). The authority managing of money not yet autonom so that impact to slowly of the claim getting mechanism. Limitation human resources implicated to effectiveless intitution to serve acceptener.

Key words: Local health insurance, cost system, scheme of institution

\section{Pendahuluan}

Negara menyelenggarakan Sistem Jaminan Sosial Nasional (SJSN) sebagai sistem penyelenggara program negara dan pemerintah untuk memberikan perlindungan sosial agar setiap penduduk dapat memenuhi kebutuhan dasar hidup layak. ${ }^{1}$ Jaminan sosial kesehatan bertujuan memberi kepastian perlindungan kesejahteraan sosial kesehatan agar setiap penduduk dapat memenuhi kebutuhan hidup menuju terwujudnya kesejahteraan

Alamat Korespondensi: Sunarto, Fakultas Kedokteran Universitas Islam Indonesia, Jl. Kaliurang Km. 14,5, Sleman Yogyakarta, Hp. 08156898268, e-mail: narto_darsono@yahoo.com 
sosial bagi seluruh masyarakat Indonesia. Otonomi daerah memberi peluang kepada warga negara untuk memperoleh pelayanan dasar yang lebih baik, khususnya kesehatan. Salah satu inisiasi Pemerintah Kota Yogyakarta untuk mencapai kesejahteraan masyarakat adalah kebijakan sosial. Kebijakan sosial didefinisikan sebagai suatu tindakan publik dari pemerintah maupun aktor-aktor diluar orang-orang pemerintahan untuk menyediakan kebutuhan dasar yang bersifat sosial seperti pendidikan dan kesehatan. ${ }^{2}$

Indeks Pembangunan Manusia (IPM) Kota Yogyakarta $(77,7)$ mengindikasikan tingkat kesejahteraan masyarakat yang relatif tinggi diukur dari aspek angka harapan hidup, angka melek huruf penduduk dewasa, dan paritas daya beli. Salah satu tantangan Kota Yogyakarta adalah jumlah penduduk miskin yang relatif tinggi. Berdasarkan data resmi Pemerintah Kota Yogyakarta, Keputusan Walikota No. 523 Tahun 2007, warga miskin tercatat $17 \%$ total penduduk yang tercatat resmi 525.698 jiwa, tersebar di 14 kecamatan dan 45 kelurahan. Jumlah warga miskin cenderung bergerak naik setiap tahun. Luas wilayah Kota Yogyakarta sekitar 3.250 ha atau 32,50 km dengan kepadatan penduduk mencapai 16.098 orang per $\mathrm{km}^{2}$. Data status kesehatan pada tahun 2005 yaitu angka kematian bayi $(3,57$ per 1.000 kelahiran hidup), angka kematian balita $(0,14$ per 1.000 kelahiran hidup), dan angka kematian ibu melahirkan (141 per 100.000 kelahiran hidup). Berdasarkan dokumen Rencana Pembangunan Jangka Menengah Daerah Kota Yogyakarta tahun 2007-2011, balita berstatus gizi buruk sebanyak 570, angka tuberkulosis paru sebanyak 222 per 100.000 penduduk, dan angka kesakitan diare sebesar 10,38\%.

Pemerintah kota melaksanakan kebijakan Jaminan Kesehatan Daerah (Jamkesda) yang bertujuan meningkatkan akses dan mutu pelayanan kesehatan terhadap masyarakat khususnya masyarakat miskin. Kebijakan ini didasarkan pada Peraturan Walikota No. 66 Tahun 2007 tentang Penyelenggaraan Program Jaminan Kesehatan Daerah. ${ }^{3}$ Sebelumnya, telah ada Peraturan Walikota No. 203 Tahun 2005 tentang Pembentukan Unit Pelaksana Teknis Penyelenggara Jaminan Kesehatan Daerah (UPT PJKD) dibawah dinas kesehatan. ${ }^{4}$ Dalam pelaksanaan Jamkesda, belum pernah dilakukan pengkajian ulang terkait dengan sistem pembiayaan dan skema kelembagaan sebagai bahan masukan untuk pengembangan ke depan. Tujuan penelitian ini mengetahui lebih rinci masalah utama yang berhubungan dengan sistem pembiayaan dan skema kelembagaannya.

\section{Metode}

Penelitian dengan desain studi kasus ini menggunakan metode kualitatif analisis kebijakan retrospektif yang berorientasi pada aplikasi dengan mengidentifikasi tujuan dan sasaran, membantu merumuskan masalah, mengembangkan alternatif-alternatif kebijakan baru serta merekomendasikan arah dan tindakan untuk memecahkan masalah. ${ }^{5}$ Formulasi kebijakan dan penyelenggaraan pelayanan publik dimaknai sebagai proses interaksi dialektis antara aktor negara dan warga masyarakat. Interaksi dialektis adalah realitas kehidupan sosial yang dinamis sehingga tidak mungkin dikaji secara kuantitatif dengan mengandalkan angka statistik. ${ }^{6}$ Metode penelitian kualitatif dapat memberi jalan bagi peneliti untuk mengeksplorasi secara mendalam mengenai perspektif, pengetahuan, dan praktek sosial para informan. ${ }^{7}$

Variabel utama pada penelitian ini adalah sistem pembiayaan dan skema kelembagaan. Data diperoleh melalui teknik pengumpulan data primer melalui wawancara mendalam, focus group discussion (FGD), dan working paper yang bersumber dari informan terpilih. Data sekunder diambil dari dokumentasi kebijakan. Pertama, metode wawancara mendalam, analisis kualitatif dilakukan dengan menelaah data, mengklasifikasi menjadi unit yang dapat dikelola, mensintesa, mencari pola, dan menemukan hal-hal apa yang penting. FGD dilakukan sebanyak 6 kali dengan melibatkan informan pemangku kepentingan.

Wawancara mendalam telah dilakukan dengan Wakil Walikota, Kepala Dinas Kesehatan, Ketua Komisi I DPRD, Kepala Badan Perencanaan Pembangunan Daerah, Kepala Unit Pelaksana Teknis Penyelenggara Jaminan Kesehatan Daerah, Kepala Puskesmas Umbulharjo, Direktur Rumah Sakit Umum Daerah Wirosaban, Kepala Bidang Penelitian dan Penguatan Masyarakat Lembaga Ombusman Daerah (LOD) Daerah Istimewa Yogyakarta (DIY), aktifis LSM, praktisi jaminan kesehatan penerima manfaat program Jamkesda serta warga miskin pengguna Kartu Menuju Sehat (KMS).

\section{Hasil \\ Kebijakan Jaminan Kesehatan Daerah Kota Yogyakarta}

Kebijakan didesain untuk menjamin warga kota khususnya masyarakat miskin yang belum tercakup oleh program jaminan kesehatan dari pusat (Asuransi Kesehatan untuk Masyarakat Miskin, Askeskin/Jaminan Kesehatan Masyarakat, Jamkesmas) serta program Jaminan Kesehatan Sosial (Jamkesos) dari Provinsi Daerah Istimewa Yogyakarta. Jamkesda sebagai program perlindungan sosial daerah berfungsi sebagai buffer di bidang jaminan kesehatan. Jangka panjang direncanakan menuju kebijakan jaminan kesehatan yang bersifat universal coverage.

"Jangan sampai ada warga Yogya terutama bagi masyarakat miskin yang tidak dapat mengakses pelayanan kesehatan, kalau sampai terjadi yang pertama 


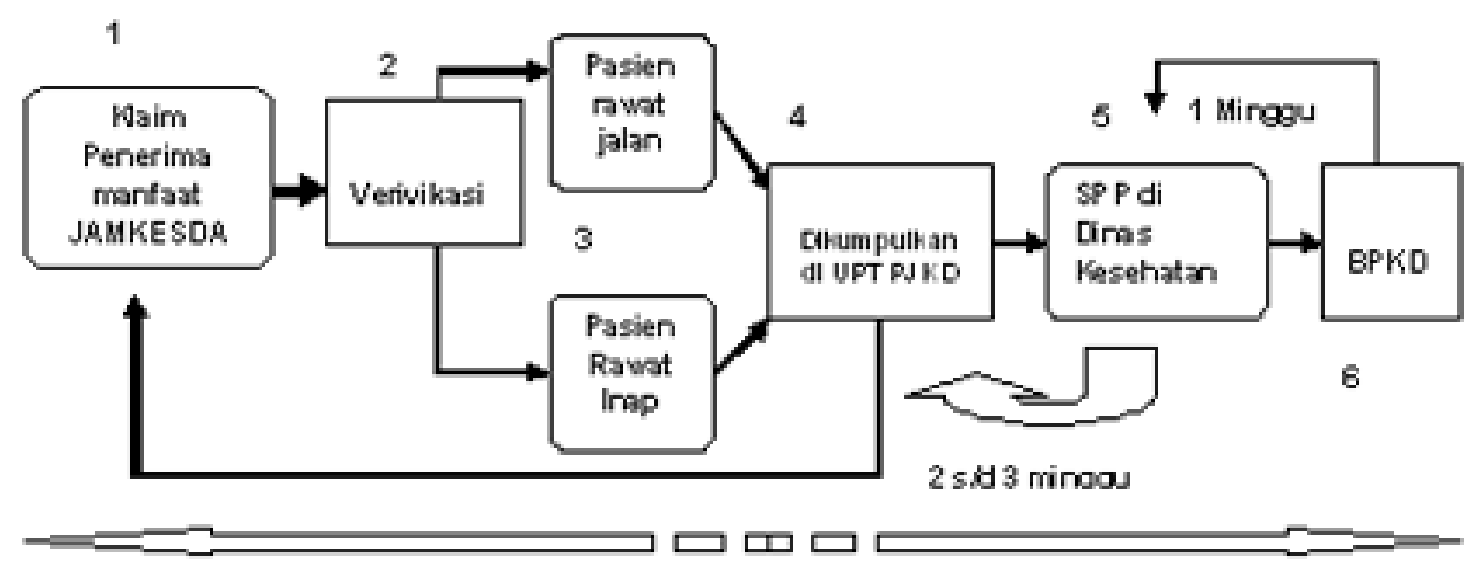

Gambar 1. Mekanisme Pencairan Dana (Klaim) Jaminan Kesehatan Daerah

harus disalahkan adalah pemerintah kota." (Wakil Walikota Yogyakarta)

\section{Sistem Pembiayaan Jaminan Kesehatan Daerah \\ Sistem Pembayaran}

Jamkesda Kota Yogyakarta menerapkan sistem pembiayaan jaminan kesehatan yang mengkombinasikan retrospective payment system dan prospectif payment dan bersifat transisional. Saat ini, Jamkesda kota belum sepenuhnya mengadopsi sistem Jaminan Pemeliharaan Kesehatan Masyarakat (JPKM). Kontrak dengan rumah sakit menggunakan model fee for service. Untuk pelayanan rawat jalan, sebagian telah dilakukan kontrak dengan dokter keluarga secara kapitasi. Beberapa penerima manfaat diluar masyarakat miskin dan kelompok khusus berdasarkan pada fee for service atau reimbursing dalam bentuk bantuan sosial.

Sistem pembiayaan Jamkesda masih bersumber pada pemerintah kota, yakni Anggaran Pengeluaran dan Belanja Daerah (APBD). Pemberi Pelayanan Kesehatan (PPK) terkadang mengalami kendala oleh pencairan klaim karena harus disesuaikan dengan mekanisme keuangan daerah. Hal ini merupakan konsekuensi sistem kerja sama atau kontrak dengan Jamkesda yang masih menerapkan sistem retrospective payment atau fee for service, meskipun kerangka acuan sudah paket.

Konsekuensi dari penerapan sistem fee for service yang didasarkan pada imbalan jasa sesuai dengan frekuensi kunjungan membutuhkan biaya yang lebih besar daripada sistem kapitasi yang didasarkan pada jumlah tetap peserta berdasarkan kapita yang ditanggung. ${ }^{5}$ Implementasi sistem ini lebih memerlukan waktu karena sumber pembiayaan masih ditanggung oleh
APBD dan dikelola oleh UPT PJKD yang harus tunduk dengan peraturan pengelolaan keuangan daerah (Lihat Gambar 1).

\section{Sumber Pembiayaan dan Alokasi Anggaran}

Sumber pembiayaan Jamkesda hanya bersumber dari APBD. Berdasarkan data dari Dinas Kesehatan Pemerintah Kota Yogyakarta pada tahun 2007 menganggarkan untuk program Jamkesda dalam APBD sebesar Rp. 4.647.568.000. Diukur dari aspek efektivitas penggunaan anggaran menurut Kepala Dinas Kesehatan telah digunakan secara strategis terutama dikaitkan dengan penerima manfaat. Data Dinas Kesehatan menunjukkan dana yang telah diserap mencapai $\mathrm{Rp}$. 1.363.570.763 dengan total penggunaan mencapai 277.421 kasus. Rincian 251.635 kasus merupakan kasus di kelompok sasaran orang miskin dan kelompok khusus yang telah dijamin dalam program Jamkesda. Tahun anggaran 2008 sampai dengan bulan Mei 2008, Pemerintah Kota Yogyakarta telah menganggarkan dana untuk program Jamkesda sebesar Rp. 6.368.544.000 dan sampai bulan Mei telah digunakan sebesar Rp. 795.785.499 dengan jumlah total kasus 1.762 kasus (Lihat Tabel 1). Terlihat ada komitmen politik pihak eksekutif dan legislatif Kota Yogyakarta yang baik dengan mendorong peningkatan alokasi anggaran dari APBD untuk program Jamkesda.

Skema Kelembagaan Unit Pelaksana Teknis Penyelenggara Jaminan Kesehatan Daerah

Secara kelembagaan, pelaksanaan program Jaminan Pemeliharaan Kesehatan Masyarakat Daerah dilaksanakan oleh UPT PJKD pada Dinas Kesehatan 
Tabel 1. Alokasi dan Sumber Pembiayaan Jaminan Kesehatan Daerah

\begin{tabular}{lll}
\hline Tahun & Dana (Rp.) & Realisasi (Rp.) \\
\hline 2006 & 3.443 .026 .750 & 2.323 .666 .954 \\
2007 & 4.647 .568 .000 & 1.363 .570 .763 \\
2008 (sampai bulan Mei) & 6.368 .544 .000 & 795.785 .499 \\
\hline
\end{tabular}

Kota Yogyakarta didasarkan pada Peraturan Walikota No. 203 Tahun 2005 tentang pembentukan UPT. Kedudukan, fungsi, dan tugas dari UPT PJKD tersebut adalah unit pelaksana teknis untuk menunjang operasional dinas kesehatan dalam bidang pelayanan asuransi kesehatan masyarakat. Pegawai daerah tersebut dipimpin oleh seorang kepala yang bertanggung jawab kepada Kepala Dinas Kesehatan. UPT PJKD ini berfungsi dalam pelaksanaan kegiatan operasional penyelenggaraan jaminan kesehatan masyarakat. Sebagai tindak lanjut dari format kelembagaan yang telah dibuat legalitas dalam Peraturan Walikota No. 203 Tahun 2005, Pemerintah Kota Yogyakarta mendesain kebijakan yang berfungsi sebagai pedoman pelaksanaan dalam bentuk Peraturan Walikota No. 66 Tahun 2007 tentang Penyelenggaraan Program Jaminan Kesehatan Daerah.

Ada beberapa permasalahan yang dihadapi oleh UPT PJKD saat ini. Beberapa permasalahan antara lain: (1) UPT PJKD belum dapat melayani klaim secara cepat. Proses keuangan yang secara khusus belum dapat dilaksanakan oleh UPT karena harus mengikuti alur proses peraturan pencairan anggaran di pemerintah kota sesuai dengan Peraturan Menteri Dalam Negeri No. 59 Tahun 2007. (2) Masih adanya kerancuan tugas pokok dan fungsi (tupoksi), dimana masih adanya persepsi yang keliru bahwa program JPKM identik dengan UPT PJKD yang membawa konsekuensi perangkat birokrasi kurang melakukan sosialisasi di wilayah kerjanya. (3) Kebijakan pemerintah pusat yang tidak konsisten. (4) Kualitas sumber daya manusia (SDM) pengelola UPT PJKD yang belum sesuai kompetensi dalam bidang asuransi kesehatan. Secara kuantitas hanya berjumlah 10 personal yang harus melayani 300-500 penerima manfaat per bulan. (5) Masyarakat masih kurang percaya terhadap penyelenggara asuransi kesehatan. (6) Masih adanya hambatan birokrasi dalam mekanisme pengurusan identitas miskin berupa KMS. Masalah ini memiliki potensi menggangu kinerja dan berdampak pada efektivitas pelaksanaan program Jamkesda.

Gambaran penilaian masyarakat terhadap lembaga pelaksana program Jamkesda dinilai masih kurang tergambar pada hasil penilaian bersama. Penilaian masyarakat terhadap mekanisme layanan di UPT PJKD terhadap penerima Jamkesda mampu memperlancar pelaksanaan program Jamkesda Kota Yogyakarta, memperoleh skor rata rata 2,445 belum mampu memperoleh skor 3 (baik). Hal ini menggambarkan bahwa mekanisme layanan di UPT PJKD masih belum membantu memperlancar pelaksanaan program Jamkesda Kota Yogyakarta.

Jumlah personil lembaga UPT PJKD yang hanya 10 personil, menurut Kepala Dinas Kesehatan menjadi salah satu kendala pelayanan. Mereka harus melakukan semua tugas yang sesuai dengan mandat Peraturan Walikota No. 203 Tahun 2005 meliputi perencanaan, pelaksanaan, sosialisasi, verifikasi, melayani klaim, dan melakukan evaluasi. Padahal, penerima manfaat yang harus dilayani rata-rata berkisar 300-500 orang per bulan. Unit layanan kesehatan terutama tingkat lanjut rumah sakit hanya ada petugas dari front line rumah sakit sendiri yang terkadang belum memahami prosedur atau mekanisme pelayanan Jamkesda. Keterbatasan jumlah personil rumah sakit yang melayani Jamkesda secara tidak langsung dapat menyebabkan pelayanan kesehatan yang diskriminasi dan kurang efektif di PPK tingkat lanjut.

Kendala pengelolaan keuangan lembaga UPT adalah peraturan pengelolaan keuangan daerah, terutama dalam melayani klaim pembayaran. Disarankan perubahan sifat kelembagaan dari UPT PJKD tersebut menggunakan prinsip-prinsip pengelolaan Badan Layanan Umum (BLU). Sifat kelembagaan berupa BLU ini lebih fleksibel dan efektif dalam bergerak. Lembaga dalam pengelolaan keuangan ini tetap harus tunduk pada Peraturan Menteri Dalam Negeri No. 59 Tahun 2007 hanya untuk yang didanai oleh APBD, selebihnya dapat dengan kepengelolaan sendiri sesuai dengan sistem yang dibangun. Badan ini dapat melakukan kegiatan lain berupa pengelolaan barang dan jasa serta mengembangkan uang sesuai dengan ketentuan. Pengelola dapat menarik peserta dari masyarakat yang mengikuti programnya secara sukarela. Diharapkan dapat terjadi mekanisme subsidi silang antara kelompok sehat kepada kelompok sakit atau antara yang mampu secara ekonomi dengan yang kurang mampu sesuai dengan prinsip asuransi sosial. Subsidi silang antara yang mampu dengan yang tidak mampu akan mengurangi beban APBD secara bertahap 
mengikuti perkembangan kepesertaan baru.

Pendapat yang berbeda menurut praktisi jaminan kesehatan, Irianto, 13 bahwa yang dilakukan oleh Pemerintah Provinsi dan Kabupaten/Kota se-Provinsi Daerah Istimewa Yogyakarta yang telah mengembangkan sistem jaminan kesehatan bagi masyarakat sudah sesuai dengan Peraturan Pemerintah (PP) No. 38 dan Peraturan Pemerintah No. 41 Tahun 2007 tentang Kewenangan Daerah Bidang Kesehatan. Prinsipnya, setiap kabupaten/kota mendirikan badan jaminan sudah sesuai dengan Peraturan Pemerintah yang ada. Ditetapkannya struktur organisasi tata laksana kelembagaan badan jaminan berbentuk UPTD maka kelembagaan badan jaminan secara legal aspek telah memenuhi ketentuan yang berlaku.

"Dalam pelaksanaan program jaminan hendaknya antarbadan pengelola bisa saling bersinergi, baik dalam hal paket pelayanan, rumah sakit yang dikontrak maupun pola tarif yang digunakan. Sebaiknya, pelaksanaan program jaminan kesehatan lebih diprioritaskan pada memperluas cakupan kepesertaan daripada memberikan bantuan pembiayaan yang tidak dijamin oleh badan asuransi lainnya. Hal ini karena ke depan sudah seharusnya terjadi kendali biaya di pemberi pelayanan kesehatan.” (Direktur Jamkesos DIY)

Berdasarkan hasil pengamatan Direktur dan pengalaman Jamkesos DIY, saat ini pihak PPK cukup merasa nyaman dengan telah diberlakukannya program jaminan. Ada kepastian pembayaran oleh badan penyelenggara daerah, Jamkesos, dan Jamkesda. Saat ini, piutang yang terjadi di rumah sakit relatif kecil dibanding sebelum dilaksanakan program Jamkesda.

Berdasarkan hasil penilaian masyarakat dengan menggunakan metode citizen report card (CRC) terhadap tingkat keberhasilan program Jamkesda Kota Yogyakarta telah dapat membantu pembiayaan kesehatan masyarakat dan memperoleh skor rata-rata 2,78. Dilihat dari varian penilaian warga yang memberikan penilaian skor 3 di 2 tempat masing-masing, Kelurahan Tegal Panggung mencapai 59\% sementara di Kelurahan Warung Boto mencapai 70\%. Hal ini menggambarkan sesungguhnya program ini sangat membantu pembiayaan kesehatan warga masyarakat Kota Yogyakarta yang membutuhkan.

\section{Pembahasan}

\section{Kebijakan Jaminan Kesehatan Daerah Kota Yogyakarta}

Rencana Pembangunan Jangka Menengah Daerah (RPJMD) tahun 2007-2011 dalam bentuk Peraturan Walikota No. 17 Tahun 2007 berisi misi mewujudkan Kota Yogyakarta Sehat. Hal tersebut hendak dicapai melalui penyediaan pelayanan kesehatan yang memadai, penyediaan sarana dan prasarana kesehatan yang baik, kebijakan dan sistem kesehatan masyarakat kota yang mantap, penyediaan SDM yang berkualitas dan mem- punyai kompetensi tinggi serta didukung oleh partisipasi masyarakat. ${ }^{8}$ RPJMD ini diturunkan dalam kebijakan Rencana Aksi Daerah (RAD) mewujudkan Yogyakarta Kota Sehat tahun 2007-2011 yang tertuang dalam Keputusan Walikota No. 603/KEP/Tahun 2007 yang dijadikan panduan dalam mendesain kebijakan Jamkesda. Kebijakan Jamkesda ini merupakan political will dari pihak pemerintah kota dengan dukungan dari DPRD.

Kebijakan Jamkesda tersebut didasarkan pada kebutuhan meningkatkan akses dan kualitas pelayanan kesehatan bagi warga Kota Yogyakarta khususnya masyarakat miskin. Kebijakan berbasis pada kebutuhan warga miskin terhadap aksesibilitas dan kualitas pelayanan kesehatan dasar dan lanjut. Jamkesda yang bersumber dari APBD menanggung penuh biaya kesehatan. Kebijakan Jamkesda merupakan komitmen Kota Yogyakarta dalam membangun suatu sistem jaminan sosial daerah yang didasarkan pada amanat UndangUndang Pemerintah Daerah No. 32/2004, terutama pasal 22 dan 167.' Jamkesda ini berawal pada tahun 2005 ketika ada program Askeskin dari pemerintah pusat yang didasarkan pada kuota penerima sementara, ada selisih sekitar 20.252 jiwa yang belum terjamin oleh program askeskin.

Sistem pembiayaan dengan model praupaya merupakan kritik terhadap sistem retrospective payment yang berupaya mencegah atau mengendalikan biaya kesehatan dan penggunaan sarana kesehatan yang berlebih. Istilah pembiayaan kesehatan disebut sebagai the law of medical money yang berarti hukum biaya kesehatan akan naik sampai batas kemampuan keuangan. Konsep praupaya pada intinya pembayaran peserta program jaminan ditetapkan sesuai dengan diagnosis penyakit dan ditetapkan sebelum suatu pelayanan medik dilakukan oleh pihak PPK. Pendekatan ini akan mendorong insentif financial pada pihak PPK untuk mengantisipasi penggunaan sarana kesehatan yang berlebih dan menurunkan length of stay (LOS). ${ }^{9}$ Mekanisme pencairan dana dari pihak UPT PJKD yang relatif lambat dan kurang efektif akan mengganggu biaya operasional puskemas rawat inap. Hal tersebut disebabkan oleh keterlambatan anggaran dari pusat dan alokasi anggaran yang terus berubah-ubah. Anggaran yang harus turun awal tahun, baru turun pada akhir tahun. Hal tersebut telah berlangsung sejak tahun 2006, 2007, dan 2008.

\section{Sistem Pembayaran}

Secara konseptual, kebijakan Jamkesda Kota Yogyakarta merupakan sebuah kebijakan yang berbasis pada konsep JPKM. Sistem ini intinya adalah pengelolaan dan keterpaduan antara pelayanan kesehatan dengan pembiayaan yang diwujudkan dalam kendali mutu dan kendali biaya. ${ }^{9}$ Suatu sistem pembiayaan kesehatan yang dilakukan di muka (praupaya) yang berdasarkan kapi- 
tasi. Konsep kapitasi dalam sistem ini berarti bahwa pembayaran imbalan jasa pelayanan pada PPK didasarkan pada jumlah kapita atau jiwa yang ikut dalam program tersebut, baik peserta sakit ataupun tidak, pembiayaan wajib diberikan. Secara prinsip, konsep manage care berbeda dengan sistem asuransi kesehatan konvensional yang berbasis pada fee for services. Pembiayaan kesehatan diberikan berdasarkan penggunaan jasa/fasilitas dan kemudian dipenuhi pembayaran jasa tersebut. ${ }^{9}$

Konsekuensi dari penerapan sistem fee for service yang didasarkan pada imbalan jasa sesuai dengan frekuensi kunjungan membutuhkan biaya yang lebih besar daripada sistem kapitasi yang didasarkan pada jumlah tetap peserta berdasarkan kapita yang ditanggung. ${ }^{5}$ Implementasi sistem ini lebih memerlukan waktu karena sumber pembiayaan masih ditanggung oleh APBD dan dikelola oleh UPT PJKD yang harus tunduk dengan peraturan pengelolaan keuangan daerah.

Total alokasi waktu yang dibutuhkan dalam mekanisme klaim berada pada kisaran 1-1,5 bulan. Tahapan pencairan dana menjadi relatif lama. Keterlambatan dapat mengganggu cash flow lembaga PPK terutama untuk biaya bagi pasien rawat inap. Pihak PPK rumah sakit dan puskesmas mengatasi masalah tersebut dengan dana operasional atau dana kapitasi dari Jamkesmas dan Jamkesos selama jumlah tagihan tidak terlalu besar. Sedangkan, dari penerima manfaat dari program Jamkesda, model kebijakan reimbursing ini dinilai masih kurang efektif. Ada 2 aspek yaitu pertama, aspek lamanya waktu klaim yang diajukan. Kedua, dari aspek pembiayaan, para penerima harus mengeluarkan biaya terlebih dahulu pada saat mengakses layanan kesehatan, baik pada tingkat dasar maupun lanjut. Satu hal yang harus dipenuhi dalam penyelenggaraan program asuransi kesehatan adalah aspek efisiensi, standar, dan kualitas pelayanan. Efisensi diperlukan agar dana yang tersedia dapat memberi manfaat maksimal. Hal ini diperlukan agar kenaikan biaya pelayanan kesehatan dapat dikendalikan sehingga premi tidak meningkat dari tahun ke tahun dan akan memberatkan masyarakat. ${ }^{9}$

Kebijakan pembiayaan pelayanan kesehatan pada suatu negara meliputi 3 sistem. Pertama, sistem pembiayaan kesehatan model Eropa yang memandang bahwa kesehatan adalah barang publik. Pelayanan kesehatan perlu disediakan oleh negara, misalnya National Health Sevices di Inggris yang merupakan negara kesejahteraan. Kedua, sistem pembiayaan kesehatan ala Amerika Serikat yang memandang kesehatan sebagai private goods. Pelayanan kesehatan diperjualbelikan melalui mekanisme pasar secara kompetitif. Ketiga, sistem kombinasi keduanya yang biasanya diterapkan di negara-negara berkembang. ${ }^{10}$

\section{Skema Kelembagaan}

Ada beberapa rekomendasi yang diberikan para pemangku kepentingan untuk meningkatkan efektivitas kelembagaan pengembangan jaminan kesehatan daerah menuju universal coverage. Beberapa rekomendasi tersebut adalah alternatif bentuk kelembagaan model BLU dan bentuk badan usaha milik daerah (BUMD) atau Perseroan Terbatas. Informan penelitian ini sebagian besar merekomendasikan untuk memilih model BLU sebagai model pengelolaan Jamkesda yang relatif efektif dan sesuai dengan semangat pelayanan publik. ${ }^{11-13}$ Tidak menutup kemungkinan jika dikelola dalam bentuk BUMD, tetapi harus tetap melalui tahapan BLU. Pengelolaan Jamkesmas bukan semata masalah mekanisme finansial, tetapi juga masalah pilihan ideologi. Menurut Vladimir Rays, ${ }^{9}$ Sekretaris Jenderal International Social Security (ISSA), bahwa ideologi social security adalah keadilan sosial dan perlindungan sosial.

Komitmen politik Pemerintah Kota Yogyakarta merupakan salah satu indikator mewujukan sistem jaminan sosial kesehatan yang mampu memenuhi kebutuhan warga Kota Yogyakarta. Ruang hukum di tingkat nasional telah memberikan peluang dalam bentuk hasil judicial review Undang-Undang No. 40 Tahun 2004 Sistem Jaminan Sosial oleh Mahkamah Konstitusi akhir bulan Agustus tahun 2005. Pasal yang bernuansa monopoli oleh 4 badan usaha milik negara (BUMN) sosial, yaitu Jaminan Sosial Tenaga Kerja (Jamsostek), Tabungan dan Asuransi Pegawai Negeri (Taspen), Asuransi ABRI (Asabri), dan Asuransi Kesehatan (Askes) telah dicabut. Judicial review tersebut membuka peluang bagi pemerintah daerah untuk menyelenggarakan sistem jaminan sosial daerah. Undang-Undang Pemerintah Daerah No. 32 Tahun 2004 mengamanatkan pemerintah daerah untuk menyelenggarakan jaminan sosial di daerahnya (pasal 22 dan 167) yang disebut dengan Jamsosda. ${ }^{14}$

Hasil judicial review ini menjadi kendala pelaksanaan yang dihadapi oleh Pemerintah Kota Yogyakarta berkaitan dengan status legal kelembagaan badan penyelenggara Jamkesda. Menurut Kepala Dinas Kesehatan, persoalan regulasi di tingkat pusat relatif masih belum jelas memberikan payung hukum bagi badan penyelenggara. Peraturan pemerintah tentang pelaksanaan Undang-Undang SJSN belum terbit. Perubahan terhadap pilihan model kelembagaan badan penyelenggara Jamkesda relatif disikapi dengan hatihati.

Perspektif hukum mengelola Badan Penyelenggara Jaminan Sosial (BPJS) memang masih ada perbedaan di tingkat pusat. Pendapat pertama bahwa tafsir hukum atas judicial review tersebut bukan berarti menyangkal keempat badan asuransi yang disebutkan dalam Undang- 
Undang SJSN. Kaidah hukum menetapkan bahwa setelah keempat badan penyelenggara yang ada menyesuaikan Peraturan Pemerintah dan peraturan lainnya sesuai dengan Undang-Undang SJSN maka keempat badan tersebut sah menjadi BPJS menurut Undang-Undang SJSN. Undang-Undang baru diperlukan jika akan dibentuk BPJS yang baru. ${ }^{15}$ Pihak yang berbeda menyimpulkan bahwa keempat BPJS yang diatur Pasal 5 ayat 3 pada Undang-Undang SJSN yang dibatalkan oleh Mahkamah Konstitusi. Adanya judicial review, otomatis keempat BPJS tersebut tidak lagi memegang hak atau amanat Undang-Undang SJSN sehingga daerah bebas mengembangkan BPJS daerah. Paham ini dianggap semata-mata hanya melihat pasal yang dibatalkan oleh Mahkamah Konstitusi tanpa melihat pasal-pasal lain dan argumen Mahkamah Konstitusi dalam membatalkan pasal tersebut yang semata-mata dapat multitafsir.

Undang-Undang No. 32 Tahun 2004 Pasal 22 ayat 1 huruf $\mathrm{h}$ berbunyi: Pemerintah daerah wajib mengembangkan sistem jaminan sosial. Konteks dan pemahaman pembuat Undang-Undang No. 32 Tahun 2004 sesungguhnya dapat dipastikan bahwa kata jaminan sosial dalam Undang-Undang Otonomi Daerah tersebut bersifat umum dan berbeda dengan makna yang dirumuskan oleh Undang-Undang SISN yang bersifat khusus lex specialist. Makna jaminan sosial dalam Undang-Undang No. 32 Tahun 2004 bersifat umum yang dipahami masyarakat seperti mengurus anak terlantar, penduduk jompo, pengangguran, korban pemutusan hubungan kerja (PHK), gelandangan, korban bencana alam, dan sebagainya. Kata jaminan sosial yang menjadi kewajiban pemerintah daerah adalah pelayanan sosial yang bersifat sementara dan lokal. Sementara, Undang-Undang SISN hanya mengatur 5 program jaminan yang bersifat jangka panjang yang berlaku seumur hidup bagi seluruh rakyat secara nasional. ${ }^{15}$ Kata jaminan sosial dalam UndangUndang Otonomi Daerah tersebut tidak dimaksudkan jaminan kesehatan sebab klausa yang menyangkut kesehatan sudah diatur sebagai kewajiban pemerintah daerah dalam pasal yang sama huruf $\mathrm{f}$ menyebutkan pemerintah daerah wajib menyediakan fasilitas kesehatan. Kata fasilitas kesehatan yang mencakup pendanaan, peralatan, dan sumber daya manusia.

\section{Kesimpulan}

Kebijakan Jamkesda Kota Yogyakarta berlandaskan legalitas berupa Peraturan Walikota No. 203 tahun 2005 tentang pembentukan UPT PJKD pada dinas kesehatan. Implementasinya diperkuat dengan Peraturan Walikota No. 66 Tahun 2007 tentang Penyelenggaraan Program Jamkesda Kota Yogyakarta. Sistem pembiayaan yang digunakan belum sepenuhnya menerapkan sistem prospective payment atau praupaya tetapi masih mengkombinasikan dengan sistem retrospective pay- ment. Alokasi anggaran yang disediakan relatif mencukupi, efektif, berkelanjutan, dan secara bertahap menuju ke arah universal coverage. Berdasarkan skema kelembagaan, UPT PJKD relatif belum dapat melayani klaim secara cepat dan masih ada kerancuan pelaksanaan serta sosialisasi kepada masyarakat yang kurang. Kualitas sumber daya manusia pengelola UPT PJKD yang belum sesuai kompetensi dalam bidang asuransi kesehatan. Berdasarkan penilaian masyarakat dengan menggunakan metode CRC, program Jamkesda Kota Yogyakarta telah dapat membantu pembiayaan kesehatan masyarakat dan memperoleh skor rata-rata 2,78 dari skor maksimal 4.

\section{Saran}

Perlu dikembangkan alternatif sumber pembiayaan dari luar APBD untuk mengatasi keterbatasan APBD Kota Yogyakarta. Perlu disiapkan regulasi dalam bentuk sistem kesehatan daerah yang mencantumkan sistem pembayaran yang mengatur tentang jaminan sosial kesehatan yang berbasis pada prospective payment. Berbagai variannya dapat dengan pendekatan model DRG's (Diagnostic Related Groups), model tarif harian rumah sakit atau sistem kapitasi. Sifat kelembagaan Jamkesda Kota Yogyakarta dalam rangka menuju total penjaminan perlu dikembangkan model corporatism social insurance. Berdasarkan rekomendasi dari para stakeholder, sebagian besar merekomendasikan untuk memilih bentuk kelembagaan BLU sebagai model pengelolaan Jamkesda yang relatif efektif dan sesuai dengan semangat pelayanan publik.

\section{Daftar Pustaka}

1. Departemen Kesehatan Republik Indonesia. Undang-undang no. 40 tahun 2004 tentang sistem jaminan sosial nasional. Jakarta: Departemen Kesehatan Republik Indonesia; 2004.

2. Maureen, McIntoch, Tinbandebage, Paula. Inequality and redistribution in health care: analytical issues for development social policy. Jenewa: United Nation Research Institute for Social Development; 2006.

3. Pemerintah Daerah Yogyakarta. Peraturan walikota Yogyakarta no. 66 tahun 2007 tentang penyelenggaraan program jaminan kesehatan daerah Kota Yogyakarta tahun 2007. Yogyakarta: Pemerintah Daerah Yogyakarta; 2007.

4. Pemerintah Daerah Yogyakarta. Peraturan walikota Yogyakarta no. 203 tahun 2005 tentang pembentukan unit pelaksana teknis penyelenggarakan jaminan kesehatan daerah pada Dinas Kesehatan. Yogyakarta: Pemerintah Daerah Yogyakarta; 2005.

5. Dunn WN. Pengantar analisis kebijakan publik. Yogyakarta: Gajah Mada University Press; 2003.

6. Suyuno A. Teori strukturasi untuk analisa sosial Pasuruan Jawa Timur. Jakarta: Penerbit Pedati; 2003.

7. Flick U. An introduction to qualitative research. London: Sage Publication; 1998.

8. Pemerintah Daerah Yogyakarta. Peraturan walikota Yogyakarta no. 17 tahun 2007 tentang rencana pembangunan jangka menengah daerah 
(RPJMD) Kota Yogyakarta tahun 2007-2011. Yogyakarta: Pemerintah Daerah Yogyakarta; 2007.

9. Sulastomo. Manajemen kesehatan. Jakarta: Gramedia Pustaka Utama; 2000.

10. Murti B. Dasar-dasar asuransi kesehatan. Yogyakarta: Penerbit Canisius; 2000.

11. Anwar C. Desain kebijakan jaminan kesehatan daerah untuk pemenuhan hak dasar warga Kota Yogyakarta. Yogyakarta: Dinas Kesehatan Kota Yogyakarta; 2008.
12. Sunarto. Penyelenggaraan jaminan kesehatan masyarakat Kota Yogyakarta. Yogyakarta: Kertas Kerja; 2008.

13. Irianto S. Program jaminan kesehatan saat ini dan masa yang akan datang. Yogyakarta: Kertas Kerja; 2008.

14. Sekretaris Negara. Undang-undang no. 32 tahun 2004 tentang pemerintah daerah. Jakarta: Sekretaris Negara; 2004.

15. Thabrany H. Urgensi, konseptualisasi, dan operasionalisasi jaminan kesehatan universal di kota dan kabupaten di seluruh Indonesia. Yogyakarta: Makalah Diskusi Terbatas Jangkep; 2007. 